\title{
Poly(L-Cysteine) Modified Pencil Graphite Electrode for Determination of Sunset Yellow in Food and Beverage Samples by Differential Pulse Voltammetry
}

\author{
Ozge Koyun and Yucel Sahin* \\ Department of Chemistry, Faculty of Arts \& Science, Yildiz Technical University, TR34210 Istanbul, \\ Turkey. \\ *E-mail: yucelsahin06@gmail.com
}

doi: $10.20964 / 2018.01 .40$

Received: 12 September 2017 / Accepted: 29 October 2017 / Online Published: 1 December 2017

\begin{abstract}
In this study, we have focused on the use of a poly(L-cysteine) (PLC) modified pencil graphite electrode (PGE) as a sensor for determination of Sunset Yellow (SY). The performance of the modified electrode was studied using cyclic voltammetric and differential pulse voltammetric method. The modified electrode was characterized by electrochemical impedance spectroscopy, cyclic voltammetry and Fourier transform infrared spectroscopy. The surface of the modified electrode was examined by scanning electron microscope. The electrochemical behavior of SY in phosphate buffer solution ( $\mathrm{pH}$ 7.0) was examined using unmodified PGE and PLC modified PGE (PLC/PGE). The results showed that the electrochemical response of PLC/PGE to SY was significantly developed. The PLC/PGE showed linear responses in the electrochemical oxidation of SY between the concentration values of $1.0 \mu \mathrm{M}$ and $1000 \mu \mathrm{M}$. The sensor (PLC/PGE) showed a good response for SY with a detection limit of $0.125 \mu \mathrm{M}(\mathrm{S} / \mathrm{N}=3)$. Analytical application of PLC/PGE was successfully tested in the determination of SY in food and beverage samples.
\end{abstract}

Keywords: Sunset yellow; Poly(L-cysteine); Electropolymerization; Pencil Graphite Electrode; Food Additive

\section{$\underline{\text { FULL TEXT }}$}

(C) 2018 The Authors. Published by ESG (www.electrochemsci.org). This article is an open access article distributed under the terms and conditions of the Creative Commons Attribution license (http://creativecommons.org/licenses/by/4.0/). 